INDEPENDENT JOURNAL OF MANAGEMENT \& PRODUCTION (IJM\&P)

http://www.ijmp.jor.br

v. 11, n. 8, Special Edition ISE, S\&P - May 2020

ISSN: 2236-269X

DOI: 10.14807/ijmp.v11i8.1232

\title{
INSTITUTIONALIZATION OF THE AGRARIAN MARKET IN UKRAINE AND EUROPEAN ECONOMIC COMMUNITY: GENESIS, EVALUATION AND ANALYSIS
}

\author{
Roman Lohosha \\ Vinnytsia National Agrarian University, Ukraine \\ E-mail:Romalrv@rambler.ru
}

Larysa Mykhalchyshyna National University of Life and Environmental Sciences of Ukraine, Ukraine

E-mail: larysamykhalchyshyna@ukr.net

Anatolii Prylutskyi Vinnytsia National Agrarian University, Ukraine

E-mail:mimmoa031@gmail.com

Oksana Kubai

Vinnytsia National Agrarian University, Ukraine

E-mail: Romalrv@rambler.ru

Submission: 12/31/2019

Accept: 1/7/2020

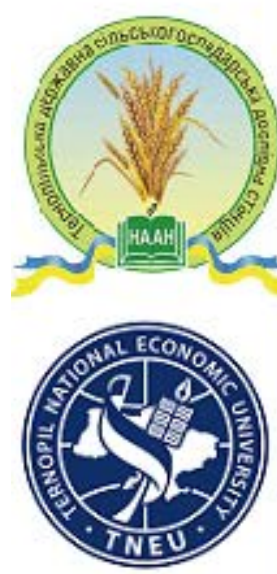

\section{ABSTRACT}

The purpose of the study was to analyse and evaluate the institutionalization of the agricultural market in Ukraine and the European Economic Community. The authors conducted a study devoted to the analysis of the regulatory and legal framework in the field of market economy building and state regulation of the agricultural market in Ukraine during the 1990s - 2020s. It is substantiated that the shortcomings of market reforms and dysfunctions of the agrarian market due to lack of scientific understanding of the role of the factor of normative and legislative support of the processes of market reforms in general, the formation of sectoral markets, as well as their effective functioning by the criterion of timely response to dysfunctions. The study was based on systematic and benchmarking methods. The tasks of the study were solved using such methods as: systematic, historical, deductive, inductive, analysis and synthesis, statistical and comparative analysis. 
DOI: 10.14807/ijmp.v11i8.1232

The theoretical provisions of institutional theory in the context of the formalization of the agrarian market institute in Ukraine and the European Economic Union and proved the need to follow the logical coherence and complexity of its institutional support as a necessary element of market reforms in the study has further developed. A model of the process of institutional support of market reforms in Ukraine is proposed. The final stage of the institutionalization of the agrarian market in Ukraine is the achievement of conditions of equivalent market exchange. Keywords: institutionalization; agrarian market; institutional changes; state regulatory policy; formalization of institutions.

\section{INTRODUCTION}

The process of accelerated formation of market fundamentals of the economy since the beginning of the 1990s was unprecedented in scale for the Ukrainian society, accompanied by sufficiently active legislative activity at the level of adoption of the Laws of Ukraine, resolutions and decrees of the Cabinet of Ministers, Decrees of the Presidents of Ukraine. It should be noted that such legislative formalization was apparently influenced by a large number of factors, many of which were uneconomic, so there is reason to argue for some inconsistency in the process; moreover, one cannot ignore the lack of experience of such reforms, which made it impossible to avoid mistakes, miscalculations, etc.

For our part, we believe that the description of the chronology and the course of adoption of legislative acts on the formation of a market economy in Ukraine requires a detailed analysis to determine the peculiarity, dysfunction and prospects of such in the future. On the other hand, the scientific description of the course of market formation was considered as an algorithm of certain logical actions and processes, the violation of which was accompanied by a decrease in the effectiveness and efficiency of reforms.

The relevance of the study is confirmed by the presence of such problems of modern management of the agricultural market in Ukraine, such as low efficiency of administrative decisions in the agrarian sector, degradation of rural settlements and, consequently, aggravation of social problems in the countryside, a long process of transformation of land relations to modern management principles, incompleteness and weakness of the normative and legal basis in the development of the agrarian market that accompanies the process of agrarian reform.

The importance of the study is determined not only by the specific features of the agrarian market existing in the country, but also by dysfunctions and some general conditions of functioning, which generally reflect the formalization of agrarian market institutions in Ukraine. 
ISSN: 2236-269X

DOI: 10.14807/ijmp.v11i8.1232

\section{LITERATURE REVIEW}

In the historical, historical, economic, political and economic literature there are various approaches to the issue of agrarian reform and formalization of the formation and development of the agrarian market, as the main direction of integration of transition countries in the market economy.

There are various approaches to the issue of state regulation and formalization of agrarian market institutions in the scientific literature, as the main direction of integration of transition countries in the market economy.

In the period before and after the collapse of the USSR, in the economic literature on agrarian transformations in the conditions of transformation of economic relations, many scientific works appeared, in which an attempt was made to substantiate and develop new directions of state regulation and development of agrarian market institutes.

The theoretical and methodological foundations in the post-Soviet space, related to the formation and development of the agrarian market and its institutions, were considered by many scientists, which created a scientific basis for studying the problems of the formation of the agrarian market and management of land relations at the present stage of social and economic reforms. The development of these problems is devoted to the work of such famous scientists as: Abalkin (1990), Andrianov (1996), Ashurov (2006), Belyaeva (1996), Borisenko (1993), Bochkov (2008), Bystrov (1996), Gafurov and Vohidov (2004), Gushchin (2009), Deryabin (2001), Dorofeeva (1996), Zeldner (2000), Maslenikova (1998), Novitsky (2000), Pavlova (1998), Paptsov (1991), Popov (1999), Sagaidak (2002), Serova (1996), Tambovtsev (1998), Fokin (1998), Epstein (1992), Yangiboev (2004) and others.

The problems of the agrarian market through the prism of institutional theory in their writings at various times were investigated by such scholars as North (1990), Koretskyi (2002), Coase (1960), Haidutskyi (1999), Latinin (2005), Mesel-Veseliak (2011), Sabluk (2011), Malik (2011), Shpikulyak (2010) and others are devoted to the research of problems of determining the role and place of the institutes (institutes) in the regulation of the agrarian market in Ukraine.

The researches of such scholars covered the issues of state regulation in different branches of agriculture from different points of view, the analysis of world experience and the possibility of its use in the domestic agrarian sector. Therefore, the purpose of this study is to 
DOI: 10.14807/ijmp.v11i8.1232

analyze the process of forming a regulatory framework in the field of building a market economy and agrarian market in Ukraine.

However, the number remains insufficiently conducted scientific studies of the formalization of the agrarian market institutionalization, which leads to the conclusion that not all aspects of the institutional development of the agrarian market have been considered.

The purpose of the research is to analyze the process of formalization of agrarian market institutions in Ukraine, to summarize the experience of formation, transformation of the agrarian market and to identify promising directions of its development.

\section{RESEARCH METHODOLOGY}

Theoretical and methodological basis of the study are the fundamental conclusions, provisions, concepts and hypotheses, outlined in the works of foreign and domestic scientists on the institutionalization of the agricultural market in modern market conditions. Throughout the study, the authors sought to adhere strictly to the principles of historicism and objectivity, which were the main worldviews when considering any of the questions raised. Both of these principles are in dialectical unity, as if complementary, and at the same time inextricably linked to dialectics.

The study was based on systematic and benchmarking methods. The research tasks were solved with the use of such methods of scientific knowledge as: systematic, historical, deductive, inductive, analysis and synthesis, statistical

The methodology and general scientific principles of complex economic researches were the basis of the research, fundamental provisions of modern economic theory, conceptual foundations of market theory, research, position and development of leading domestic and foreign specialists. In addition, common scientific methods of empirical and theoretical research based on dialectical and systemic approaches were used.

In the course of the research, in addition to a number of general scientific methods of economic research, it was used as the main historical (to describe the retrospective of the process of formation of the regulatory framework for the formation and development of market relations) and logical (to determine the meaningful sequence of the process of formation of the legal framework in the field of market economy construction, and agrarian market in Ukraine in particular) methods of knowledge. The research methodology involved the consideration of the institutionalization of the agrarian market factor as an integral element of the market 
DOI: 10.14807/ijmp.v11i8.1232

system, where the process of managing the market formation in retrospective and algorithmic role plays a key role.

The information and empirical research base were basis for the study was the official data contained in the materials of the State Committee of Statistics, Ministry of Agrarian Policy, Ministry of Economic Development and Trade of Ukraine, Programs adopted in the country in the field of agriculture and publications of such international organizations as the World Organization for Agriculture and Food United Nations (FAO), World Bank, Organization for Economic Co-operation and Development (OECD).

The legal basis for the study is the laws of the USSR and Ukraine, decrees of the President of Ukraine and the Government's decree, the materials of the Ministry of Agriculture and the Institute of Agricultural Economics, sectoral normative acts of ministries and departments.

\section{RESULTS AND DISCUSSIONS}

The market is apparently the main institute of the capitalist economic system that naturally forms the subject of a methodology of different economic theories, approaches, and doctrines. This practice has taken place over the last 300-400 years in the context of the interpretation of classical / neoclassical political economy, neoliberalism, institutionalism, theories of state regulation of the economy, etc.

The fundamental difference between the different scientific approaches has been, and still is, the interpretation of the role of the market and regulations, their correlation, and the like. But in any case, the factor of regulation is recognized as at least important, which is ignored for objective reasons. Therefore, the scientific substantiation of regulations continues to be a topical sphere of cognitive processes.

On the other hand, the process of market reforms in the agricultural sector (and not only) continues to be actively discussed, given the numerous facts of dysfunctions that have persisted and continue to occur. The logical question is how regulations in Ukraine have contributed to this, how effective, logical, timely, etc. they have been. Therefore, a comprehensive study of the state regulation of the agricultural sector (s) and identification of directions for improving the regulation of the agricultural market at different levels is needed.

The block of the above issues can be considered more than relevant for Ukraine as a whole. 
DOI: 10.14807/ijmp.v11i8.1232

In the process of building market relations in the agrarian sphere of the economy, a number of problems of an institutional nature in Ukraine arose. Among them are: slow adaptation of market institutions and institutions to the conditions of the domestic economic system, unsatisfactory modification of old and formation of new market institutions, inconsistency of the agrarian market regulation system, institutions and institutions with traditional economic relations and absences a comprehensive vision of the conceptual principles of institutional support for the development and regulation of the agrarian market.

As noted Shpykuliak (2010), due to the unresolved many issues, the development of institutions and institutions in the country today should be immediately considered as a fundamental problem, the solution of which will contribute to the effective functioning of the agricultural market.

The direction of institutional change is determined by the previous trajectory of development (DAVID, 2000). At the same time, economic entities formed as a result of the existence of an institutional matrix seek to maintain the status quo, that is, an established institutional structure.

Research of the problems of transition of the agrarian sector to sustainable development requires consideration of the complex interaction of the real economic, social, political and environmental processes that make it the basis, which involves the use of methodology of institutional analysis, taking into account the dynamics of the institutional background, the level of institutional development, formal and informal (NORT, 2000).

The agrarian reforms carried out in Ukraine revealed the features of the transformation period. The conditions created, without adequate institutional support, did not produce the expected results.

According to Malik (2011), the causes of the negative effects of the reforms lie in the inadequate level of government regulation of agriculture and the underestimation of the influence of informal institutions.

As noted Gyivoronskiy (2003), there are several main directions of state participation in the regulation of agrarian relations, namely: implementation of agrarian reform, which is associated with the processes of stocking and privatization of property and land of agricultural enterprises; the continuation of structural changes in the agricultural sector and the related clarification of the legal position of agricultural producers; definition of special conditions for participation of enterprises in financial relations, including taxation, and measures of state 
DOI: 10.14807/ijmp.v11i8.1232

support for agricultural producers; state regulation of certain activities; peculiarities of agricultural land use; forming market relations on a contractual basis, in particular through the conclusion of contracts of sale, contracting, delivery of agricultural products; providing services to producers; on material and technical support of agricultural production; control over the quality and safety of agricultural production; support for research, training for the village; rural development.

An important methodological aspect of state regulation of the agrarian sector of the economy is also the relationship between the stated goal and the achieved result. The inconsistency of goal and result is a fundamental characteristic of state regulation, which determines its continuous nature, since every achieved result inevitably sets new goals that need to be fulfilled in the changed conditions (DATSIY, 2005).

The widespread view is that the policy of state regulation of the agrarian market in Ukraine should provide for the optimal combination of free market relations with state intervention in the sphere of agriculture. The mechanism of implementation of regulatory measures should be based on fundamental principles, which are also an integral part of the policy of state regulation of the agricultural market.

According to Sabluk (2002), the construction of agrarian policy must comply with such principles as systematicity and complexity; priority of the person and the peasant in determining both the goals and mechanisms of its realization; reliance on science in the formulation of policy strategies and tactics, as well as the results of their implementation, which ensures the reality of the policy.

In general, it can be noted that scientists pay considerable attention to the role of regulation in the agrarian sector of a market economy. However, the unresolved many issues regarding the expediency / necessity of the influence of the state in the current conditions of transformational changes and its degree of influence on the regulation of particular branches of agriculture, determines the relevance and need for further research. In turn, given the above sources, we can conclude that there is a lack of study of such a block of issues of regulation theory as legal support for the market, especially in the initial stages of its formation.

The intellectual complex of theory in the interpretation of the authors of this article provides an opportunity to determine the general model of construction of a market economy, including individual markets, in the context of its legal regulation, where such regulation is proposed to be implemented in the form and contracting. Thus, analyzing the above suggests 
DOI: 10.14807/ijmp.v11i8.1232

that the process of shaping the market economy in Ukraine in the legal field had some consistency and logic.

These, apparently, were formed as responses to large-scale transformational processes of formation of market relations that took place in the country, including on the basis of prevailing situational response to certain phenomena that were considered crisis or lobbied powerful structures that could bring about some changes. It is known that the period of the second half of the $80 \mathrm{~s}$ - the beginning of the 90s became critical in the time dimension.

So, obviously, the logic of the process of legal contracting in the country, which until now had a completely different economic system, had to be based on the priorities of:

a) legislative consolidation of the determining institutions of a market economy, namely: private ownership, new forms of economic activity, built on private property, the very ideology of social development on the basis of capitalism and market economy, even in any socialized version;

b) the legal definition of the activities of such forms and the system as a whole, that is, the establishment of "rules" of the new economic system;

c) legitimization of new forms of management;

d) creation of conditions for formation and expansion of modern market infrastructure, financial and monetary system, other elements of market economic system;

e) taking into account the aforementioned, that is, achievement of the previously defined priorities - the formation of conditions that would facilitate the integration of the national market into the world on the basis of improving the competitiveness of the domestic economy and improving market efficiency in Ukraine. At the same time, adjustments are made at all stages in view of new conditions, process features, dysfunctions or unexpected positive effects.

It is difficult enough to determine the sequence of all these steps: the best option, of course, was to accept everything at once. However, given the lack of experience of building a market for this generation, it still had to be consistent and logically consistent with the intentions and results obtained. Considering the above, the universal model of the process (shown in Figure 1) in our understanding envisages the following four consecutive steps during which the necessary normative legal acts must be adopted in the country: 
INDEPENDENT JOURNAL OF MANAGEMENT \& PRODUCTION (IJM\&P)

http://www.ijmp.jor.br

v. 11, n. 8, Special Edition ISE, S\&P - May 2020

ISSN: 2236-269X

DOI: 10.14807/ijmp.v11i8.1232

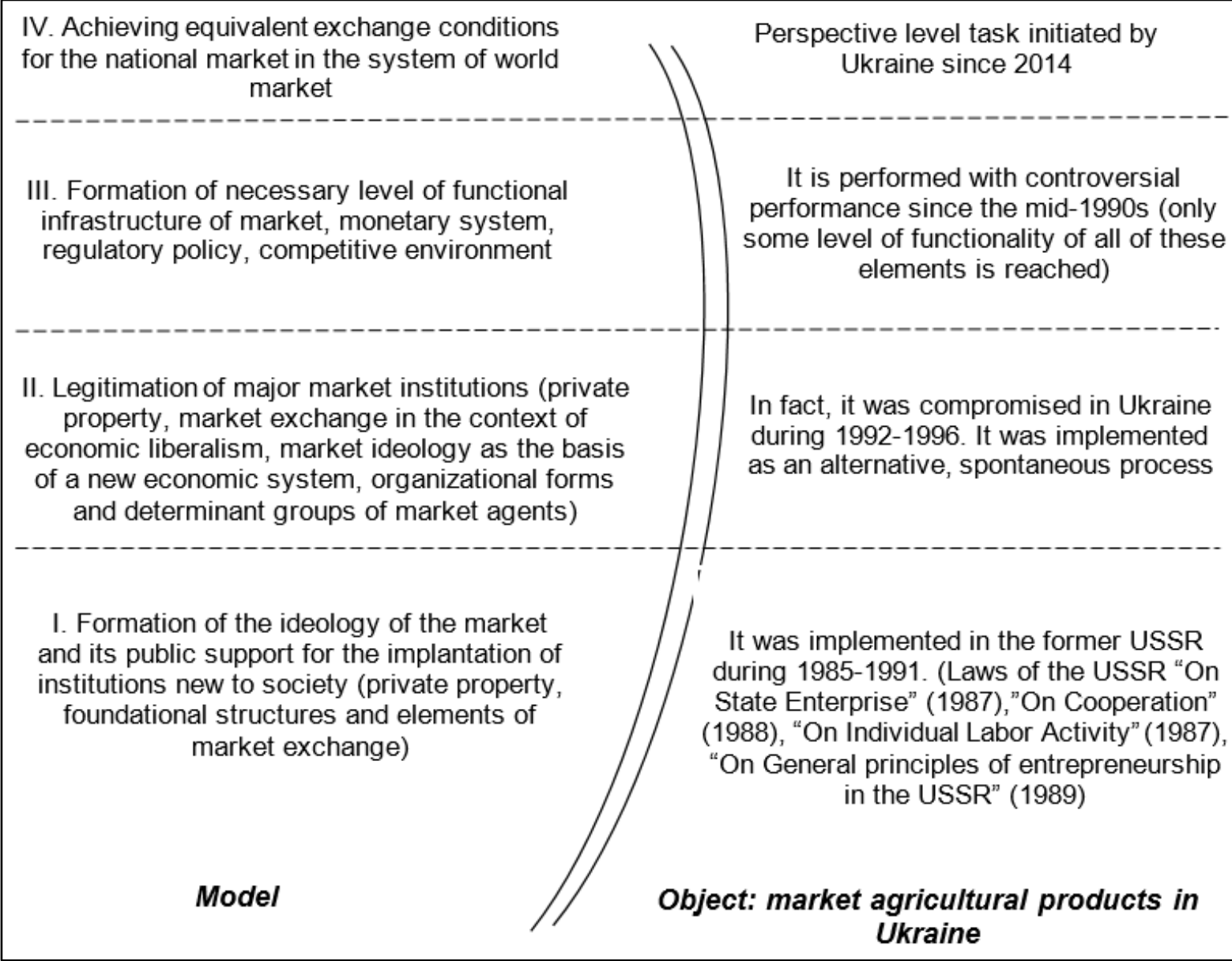

Figure 1: A paradigm model of market economy construction in the process of Ukraine entering into the world market

Source: Author's development is based on historical experience of market formation in other countries

I. Formation of market ideology in the society: the process involves political initiatives, initiated or at least agreed with the authorities, aimed at achieving public support for new (relatively new) institutions of society - private property, economic liberalism policy, market economy, market as such and some forms of market exchange, etc. In this case, we are talking about fundamentally new institutions for the society (so-called "implanted" institutions) or those that previously had little distribution or significance (i.e., institutions that were "grown up" in the domestic institutional environment). In the case of the former USSR, market institutions were not fundamentally new to society, but the mechanisms and technologies for their implementation obviously had a purely "Western” origin.

II. Establishment of market institutions: the process involves the legal legitimization of market institutions and groups of agents, which determine the very existence of the market, where, in turn, groups of agents depend on the market (recipients) and benefit from its functioning (beneficiaries). 
DOI: 10.14807/ijmp.v11i8.1232

III. Construction of the basic elements of the market and the necessary components of the market environment, first of all, the competitive environment, as well as regulatory policy, market infrastructure, monetary system, etc.

IV. Achieving conditions of equivalent exchange for the national market in the world market: the process involves achieving the appropriate - in terms of world standards level of competitiveness of the domestic economy, supply (in the context of a particular market), purchasing power and consumption, which would allow to reach the level of market equivalence sharing such standards. Ultimately, this will mean achieving an acceptable level of excellence / efficiency in the domestic market.

Figure 1 reflects not only the model of legal regulation of the process of market formation in a particular country, but also the progress of the reality specified in Ukraine. So, first of all, we would like to point out that the first stage of the formation of the ideology of the market and capitalism was actually created in the former USSR, and in independent Ukraine the process continued on a certain legal and the most importantly is ideologically formed basis of public perception of the market.

The process of accelerated formation of the market fundamentals of the economy since the beginning of the 1990s was unprecedented in scale for the Ukrainian society, accompanied by sufficiently active legislative activity at the level of adoption of the Laws of Ukraine, decrees and orders of the Cabinet of Ministers, Decrees of the Presidents of Ukraine.

It should be noted that such legislative formalization was apparently influenced by a large number of factors, many of which were uneconomic, so there is reason to argue for some inconsistency in the process; moreover, one should not ignore the lack of experience of such reforms, which made it impossible to avoid mistakes, miscalculations, etc.

For our part, we believe that the description of the chronology and the course of adoption of legislation on the formation of a market economy in Ukraine requires a detailed analysis to determine the features, dysfunctions and prospects of such for the future. On the other hand, we considered the scientific description of the course of market formation as an algorithm of certain logical actions and processes, the violation of which accompanied the decrease in the efficiency and effectiveness of reforms. Although it is obvious that much of the information below is well known, it is nevertheless necessary to re-periodize the process of determining a certain logic for the course of events. 
DOI: 10.14807/ijmp.v11i8.1232

It is advisable to carry out the count from the notorious Resolution of the CEC and RNA of the USSR "On the protection of property of state-owned enterprises, collective farms and cooperatives and the strengthening of social (socialist) property” of 07.08.1932 in order to understand the drama of the process as a whole (LAW OF USSR, 1932). In 1933, 150,000 people were sentenced under this law. The administrative system of economy with all its attributes existed in the former USSR until the mid-80's.

And in May 1986, by the Resolution of the Central Committee of the CPSU and the Council of Ministers of the USSR “On measures to strengthen the fight against non-labor income” (CPSU CENTRAL COMMITTEE AND THE COUNCIL OF MINISTERS OF THE USSR, 1986), which was formally directed against the "shadow economy" businessmen, in reality they fought, first of all, against small forms of personal economic activity.

However, the very process of market transformation in the former USSR can be associated with the process of “restructuring” during 1985-1991. The Law on State Enterprise (Association) of USSR adopted in June 1987, may be considered as fundamental (LAW OF USSR, 1987). According to this Law, the principle of economic calculation was introduced at the enterprises as the right of the enterprise to independently spend its profit, which remained after settlements with the state.

Enterprises began to plan their work independently, based on government orders, contracts concluded with suppliers and consumers, could conduct wholesale trade. The number of enterprises that had the right to enter the foreign market independently increased significantly. The role of the Union Ministries was to prepare control figures and to define government orders for enterprises. Products that were manufactured above government orders could be sold at market prices, ie in fact they were legally and mentally legitimized, which was a significant step towards the market.

On May 1, 1987, the Law of the USSR “On Individual Labor Activity” [6 LAW], which allowed individual entrepreneurship in the sphere of consumer goods and household services production, i.e. private entrepreneurship, came into force. In the beginning of 1987, 100,000 people were employed individually, in the beginning of 1988 - 300,000 people, or $0.2 \%$ of the employed.

In 1988, the Law “On Cooperation” was adopted in the USSR (LAW OF USSR, 1988), which could be associated with the legitimization of alternative organizational forms that exist 
DOI: 10.14807/ijmp.v11i8.1232

so far and the large-scale diversification of economic activity in the face of an almost total deficit in the country.

For the first time, the document was based on the determinant role of personal initiative and private property. Under this law, the citizens of the USSR were guaranteed the right to voluntarily join and leave the cooperative; participation in the management of all cooperative affairs; the independence of the collective farm and the cooperative's independence in making decisions regarding the fulfillment of its statutory tasks; the right to receive cash income from cooperative activities appropriate to the quantity and quality of work.

This law led to the emergence of a large number of different cooperatives. So, by the summer of 1988, more than 200,000 people worked in the cooperatives. According to this law, the possibility of establishing non-state banks also appeared. Until January 1, 1989, there were 41 commercial banks operating in the USSR, up to 143 by the middle of the year. As a continuation of the process, in 1989 the Law "On General Principles of Entrepreneurship in the USSR” was published (LAW OF USSR, 1989), which deepened the legal and economic foundations of the private sector. entrepreneurship, including the ability to own the means of production.

Instead, by 1990, the social and economic situation in the USSR had deteriorated significantly due to a number of circumstances that required adequate government action.

In summer of 1990, the Ryzhkov government drafted an economic anti-crisis program prepared by a working group headed by Academician Abalkin. The new policy was based on the idea of gradual, since 1991entry into the market (the so-called "first stabilization and then the market” principle), where the combination of the public sector and market relations remained.

At the same time, other government programs appeared. An alternative program of transition to a market economy, called "500 days", was prepared by a group of scientists led by Shatalin and Yavlinskyi, which envisaged, in the short term 500 days to carry out largescale privatization of state property, introduction of free market pricing with parallel indexation of wages and social benefits, as well as admission of regulated unemployment.

However, at that time, the USSR leadership favoured an economic reform program developed by USSR Finance Minister Pavlov (Prime Minister of the USSR Cabinet of Ministers in December 1990), which provided for tight state control in the transition to the market, which, in fact, neutralized the process of market formation. 
DOI: 10.14807/ijmp.v11i8.1232

Thus, the contradictions of market reforms became almost a defining feature for the former USSR. It can be argued that the issue of the market has become one of the main causes that led to the collapse of the former USSR, where the lack of a viable and prudent policy of market reforms became a catastrophic factor.

The analysis of normative legal acts on the territory of Ukraine was dated 17.10.1990, when the Law of the USSR "On the Priority of Social Development of the Village and Agroindustrial Complex in the National Economy” was adopted (LAW OF USSR, 1990), because, in our opinion, the content of this legislative document, namely its administrative focus on the regulation of the AIC, found continuation in a number of acts already after the country gained independence.

That is, the succession of the general vector of agrarian policy to the neglect of essentially constructing truly market mechanisms in the formation of a market economy in the country has become a direct economic factor, with this being very important and negative in general.

Thus, of the more than 300 pieces of legislation that were passed in Ukraine during the period 1992-2018 that were aimed at or related to the industry and the process of market reforms, we have identified about 70 , which are more or less related to influential on the formation of the agricultural market in Ukraine.

The following are evaluations of the role of these documents (that is, how much one or another document contributed to the development of the agrarian market) in the understanding of the authors of the article, which may be indicative of subjectivism.

At the same time, it was concluded that such assessment is advisable to carry out in three positions:

a) documents that had a predominant orientation on the development of market relations;

b) documents containing any elements of such orientation;

c) documents that contained mainly administrative content and had no significant impact on the development of market relations.

Another criterion for evaluation was the differentiation of legal acts into those that had a significant impact on the development of the market and those that did not have and remained declarative. 
DOI: 10.14807/ijmp.v11i8.1232

An example of the latter is the issue of soil protection under market conditions, for which the following regulatory acts were adopted: 04.08.2000 - Resolution of the Cabinet of Ministers of Ukraine “On the State Technological Center for Soil Fertility Protection” (RESOLUTION OF THE CABINET OF MINISTERS OF UKRAINE, 2000), the Law of Ukraine “On Protection lands” of 19.06.2003 (LAW OF UKRAINE, 2003), the Decree of the Cabinet of Ministers of Ukraine "On approval of the norms of the optimal ratio of crops in crop rotations in different natural and agricultural regions” of 01.02.2010 (RESOLUTION OF THE CABINET OF MINISTERS OF UKRAINE, 2010), as well as a number of others, who were called to obl to secure the protection of the land resources of Ukraine in the process of keeping agricultural land. production, and which are regarded by scientists and practitioners as being ineffective as a whole in relation to the principal declarative function.

In total, about 70 (about 26\%) of the mentioned documents were 18 (about 26\%); 18, and 33 (about 48\%) were judged to contain regulatory elements and were unrelated to the formation of market relations (as a rule, these were the regulatory acts that streamlined the procedure for carrying out technical operations on the functioning of the agricultural sector of the economy).

Quantitative proportions may not reflect the value of individual acts, but it does provide some information about what attention has been paid to particular issues.

In general, we can say that the market in the agricultural sector of Ukraine over the past 25 years was formed on the basis of about 42 regulatory acts, where, in turn, only about 18 in content and identified the features of the formation of the agricultural market in Ukraine (Table 1-3).

In this case, there were also selected acts that did not have any significant functional impact, some 10 (up to 25\%) were noted.

Table 1: The main normative and legal acts that defined the process hat ensured the formation of major market institutions

\begin{tabular}{|c|l|l|}
\hline No. & $\begin{array}{c}\text { Chronology of } \\
\text { adoption of a } \\
\text { normative and } \\
\text { legal act }\end{array}$ & \multicolumn{1}{|c|}{ Name of the normative and legal act } \\
\hline 1 & \multicolumn{1}{|c|}{2} & \multicolumn{1}{c|}{3} \\
\hline 1 & $\begin{array}{l}07.05 .1993 \quad \text { No. } \\
334\end{array}$ & $\begin{array}{l}\text { Resolution of the Cabinet of Ministers of Ukraine "On priority measures for the } \\
\text { preparation and implementation of land reform” }\end{array}$ \\
\hline 2 & $\begin{array}{l}08.08 .1995 \\
\text { No. } 720 / 95\end{array}$ & $\begin{array}{l}\text { The Decree of the President of Ukraine “On the order of stocking of lands transferred to } \\
\text { collective ownership to agricultural enterprises and organizations” }\end{array}$ \\
\hline 3 & $\begin{array}{l}28.06 .1996 \\
\text { No. 54к/96-BP }\end{array}$ & Constitution of Ukraine \\
\hline
\end{tabular}


INDEPENDENT JOURNAL OF MANAGEMENT \& PRODUCTION (IJM\&P)

http://www.ijmp.jor.br

v. 11, n. 8, Special Edition ISE, S\&P - May 2020

ISSN: 2236-269X

DOI: 10.14807/ijmp.v11i8.1232

\begin{tabular}{|c|c|c|}
\hline 4 & $\begin{array}{l}23.12 .1997 \\
\text { No. } 771 / 97\end{array}$ & $\begin{array}{l}\text { The Law of Ukraine "On the basic principles and requirements for safety and quality of } \\
\text { food" }\end{array}$ \\
\hline 5 & $\begin{array}{l}19.12 .2000 \\
\text { No. } 1348 / 2000\end{array}$ & $\begin{array}{l}\text { The Decree of the President of Ukraine "On measures to develop the cooperative } \\
\text { movement and strengthen its role in reforming Ukraine's economy on a market basis" }\end{array}$ \\
\hline 6 & $\begin{array}{l}07.08 .2001 \\
\text { No. } 601 / 2001\end{array}$ & $\begin{array}{l}\text { The Decree of the President of Ukraine "On measures to develop the food market and } \\
\text { promote exports of agricultural products and foodstuffs" }\end{array}$ \\
\hline 7 & $\begin{array}{l}24.06 .2004 \\
\text { No. } 1877-I V\end{array}$ & The Law of Ukraine "On state support for agriculture of Ukraine” \\
\hline 8 & $\begin{array}{l}18.10 .2005 \\
\text { No.2982-IV }\end{array}$ & $\begin{array}{l}\text { The Law of Ukraine "On the basic principles of state agricultural policy for the period up } \\
\text { to 2015" }\end{array}$ \\
\hline 9 & $\begin{array}{l}02.12 .2010 \\
\text { No. } 2755-V I\end{array}$ & The Law of Ukraine "Tax Code of Ukraine” \\
\hline 10 & $\begin{array}{l}31.10 .2011 \\
\text { No. } 1120-p\end{array}$ & $\begin{array}{l}\text { Resolution of the Cabinet of Ministers of Ukraine "On approval of the Concept of } \\
\text { vegetable and processing industry development" }\end{array}$ \\
\hline 11 & $\begin{array}{l}05.08 .2012 \\
\text { No. } 813\end{array}$ & $\begin{array}{l}\text { Resolution of the Cabinet of Ministers of Ukraine "On approval of the Terms and } \\
\text { Conditions for granting agricultural land to state support producers in agricultural } \\
\text { insurance crops by reducing insurance payments (premiums) and the list of agricultural } \\
\text { products of crops and types of insurance risks (products), which in } 2012 \text { are compensated } \\
\text { for the value of insurance payments (premiums)" }\end{array}$ \\
\hline 12 & $\begin{array}{l}03.09 .2013 \\
\text { No. 425-VII }\end{array}$ & $\begin{array}{l}\text { The Law of Ukraine "On the production and circulation of organic agricultural products } \\
\text { and raw materials" }\end{array}$ \\
\hline 13 & $\begin{array}{l}07.04 .2015 \\
\text { No. } 285-\text { VIII }\end{array}$ & $\begin{array}{l}\text { On Amendments to the Law of Ukraine "On State Registration of Legal Entities and } \\
\text { Entrepreneurs" to simplify the termination of legal entities by merger, accession, division, } \\
\text { transformation (reorganization) }\end{array}$ \\
\hline 14 & $\begin{array}{l}26.01 .2016 \\
\text { No.935-VIII }\end{array}$ & $\begin{array}{l}\text { On Amendments to the Law of Ukraine "On Protection of Economic Competition" to } \\
\text { Improve the Effectiveness of the System of Control over Economic Concentrations }\end{array}$ \\
\hline
\end{tabular}

Differentiation process in time, which gives an idea of the logic of the whole process is noteworthy. Thus, if we reflect the process of adopting normative legal acts on the content in the available sequence, we can conclude that the main number of such acts was adopted during 1992-1999. For example, in 2010 Legislators' attention to market issues was most likely episodic, with no clear explanation: on the one hand, the market was already created, and on the other, there was imperfection of the market, which needed some response.

Thus, if we reflect the process of adopting normative legal acts on the content in the available sequence (Table 2), we can conclude that the main number of such acts was adopted during 1992-1999.

Table 2: The main normative and legal acts that had determinant impact process of formation of the agricultural market in Ukraine *

\begin{tabular}{|c|l|l|}
\hline No. & $\begin{array}{l}\text { Chronology of adoption of } \\
\text { a normative and legal act }\end{array}$ & \multicolumn{1}{|c|}{ Name of the normative and legal act } \\
\hline 1 & \multicolumn{1}{|c|}{2} & \multicolumn{1}{|c|}{3} \\
\hline 1 & 14.02 .1992 No.2115-XII & The Law of Ukraine “On collective agricultural enterprise” \\
\hline 2 & 04.03 .1992 No. $2164-X I I$ & The Law of Ukraine “On privatization of state property” \\
\hline 3 & 10.11 .1994 No. $666 / 94$ & $\begin{array}{l}\text { The Decree of the President of Ukraine “On urgent measures to accelerate land } \\
\text { reform in the field of agricultural production” }\end{array}$ \\
\hline 4 & 17.11 .1995 No. 916 & $\begin{array}{l}\text { Resolution of the Cabinet of Ministers of Ukraine "On accelerating the } \\
\text { organization of the stock market agricultural market” } \\
\text { The Law of Ukraine "On peculiarities of property privatization in agro-industrial } \\
\text { complex" }\end{array}$ \\
\hline 5 & 10.07 .1996 No. 290/96 & \\
\hline
\end{tabular}


INDEPENDENT JOURNAL OF MANAGEMENT \& PRODUCTION (IJM\&P)

http://www.ijmp.jor.br

v. 11, n. 8, Special Edition ISE, S\&P - May 2020

ISSN: 2236-269X

DOI: 10.14807/ijmp.v11i8.1232

\begin{tabular}{|c|c|c|}
\hline 6 & 19.07.1996 No. 755 & $\begin{array}{l}\text { Resolution of the Cabinet of Ministers of Ukraine "On accelerating the } \\
\text { privatization of property in the agro-industrial complex and simplifying the } \\
\text { procedure for its implementation" }\end{array}$ \\
\hline 7 & 17.08.1997 No. 469/97-BP & The Law of Ukraine “On Agricultural Cooperation” \\
\hline 8 & 19.03.1997 No. 246 & $\begin{array}{l}\text { Resolution of the Cabinet of Ministers of Ukraine "On measures to set up wholesale } \\
\text { food markets, organize purchases of agricultural products in private sector farms, } \\
\text { reform the consumer cooperative system" }\end{array}$ \\
\hline 9 & 05.08.1997 No. 848 & $\begin{array}{l}\text { Resolution of the Cabinet of Ministers of Ukraine "On the Concept of stock market } \\
\text { agricultural products" }\end{array}$ \\
\hline 10 & 06.10.1998 No. 161-XIV & The Law of Ukraine “On Land Lease” \\
\hline 11 & 09.06.1999 No. 997 & Resolution of the Cabinet of Ministers of Ukraine "On the wholesale food markets" \\
\hline 12 & 03.12.1999 No. 1529/99 & $\begin{array}{l}\text { The Decree of the President of Ukraine "On urgent measures to accelerate the } \\
\text { reform of the agricultural sector of the economy" }\end{array}$ \\
\hline 13 & 8.08.2002. No. 694/2002 & $\begin{array}{l}\text { The Decree of the President of Ukraine "On measures to accelerate the } \\
\text { development of the agricultural market" }\end{array}$ \\
\hline 14 & 15.05.2003 No.742-IV & The Law of Ukraine "On personal peasant farms" \\
\hline 15 & 19.06.2003 No. 973-IV & The Law of Ukraine "On the farm” \\
\hline 16 & 30.08.2004. No. 1021/2004 & $\begin{array}{l}\text { The Decree of the President of Ukraine "On measures for the development of the } \\
\text { agricultural market” }\end{array}$ \\
\hline 17 & 08.12.2015 No. 867-VIII & $\begin{array}{l}\text { "On amendments to some legislative acts of Ukraine on deregulation in the agro- } \\
\text { industrial complex" }\end{array}$ \\
\hline 18 & 31.03.2016 No. 1067-VIII & $\begin{array}{l}\text { On Amendments to the Law of Ukraine "On Farming to Promote the Creation and } \\
\text { Operation of Family Farms" }\end{array}$ \\
\hline
\end{tabular}

Source: Author's generalization based on expert surveys.

Table 3: The main normative and legal acts that acts that did not have a real impact on ensure of the formation of major market institutions

\begin{tabular}{|c|c|c|}
\hline No. & $\begin{array}{c}\text { Chronology of } \\
\text { adoption of a } \\
\text { normative and legal } \\
\text { act }\end{array}$ & Name of the normative and legal act \\
\hline 1 & 2 & 3 \\
\hline 1 & $\begin{array}{l}\text { 10.04.1992 No. 2270- } \\
\text { XII }\end{array}$ & The Law of Ukraine "About leasing of state and communal property" \\
\hline 2 & $\begin{array}{l}19.10 .1999 \\
\text { No. } 1928\end{array}$ & $\begin{array}{l}\text { Resolution of the Cabinet of Ministers of Ukraine "On activation of the activity of } \\
\text { the stock market of products of the agro-industrial complex and the material and } \\
\text { technical resources necessary for its needs" }\end{array}$ \\
\hline 3 & $\begin{array}{l}\text { 19.06.2003 } \\
\text { No. 963-IV }\end{array}$ & The Law of Ukraine "On state control over land use and protection" \\
\hline 4 & $\begin{array}{l}24.02 .2010 \\
\text { No. } 196\end{array}$ & $\begin{array}{l}\text { Resolution of the Cabinet of Ministers of Ukraine "Some issues of the Agrarian } \\
\text { Exchange" }\end{array}$ \\
\hline 5 & $\begin{array}{l}07.07 .2011 \\
\text { No. } 3613-V I\end{array}$ & The Law of Ukraine "On State Land Cadastre” \\
\hline 6 & $\begin{array}{l}08.04 .2011 \\
\text { No. } 445\end{array}$ & $\begin{array}{l}\text { The Decree of the President of Ukraine “On State Agency of Land Resources of } \\
\text { Ukraine” }\end{array}$ \\
\hline 7 & $\begin{array}{l}09.02 .2012 \\
\text { No. 4391-VI }\end{array}$ & $\begin{array}{l}\text { The Law of Ukraine "On peculiarities of agricultural products insurance with state } \\
\text { support" }\end{array}$ \\
\hline 8 & $\begin{array}{l}22.04 .2013 \\
\text { No. } 364\end{array}$ & $\begin{array}{l}\text { Resolution of the Cabinet of Ministers of Ukraine “On Formation of Public Joint } \\
\text { Stock Company "Agrarian Fund” }\end{array}$ \\
\hline 9 & $\begin{array}{l}\text { 17.10.2013. } \\
\text { No. } 806-p\end{array}$ & $\begin{array}{l}\text { Resolution of the Cabinet of Ministers of Ukraine "Strategy for the development } \\
\text { of the agrarian sector of the economy for the period up to } 2020 \text { ". }\end{array}$ \\
\hline 10 & $\begin{array}{l}02.06 .2013 \\
\text { No. } 327 / 2013\end{array}$ & $\begin{array}{l}\text { The Decree of the President of Ukraine "On urgent measures to accelerate the } \\
\text { implementation of economic reforms" }\end{array}$ \\
\hline
\end{tabular}

Source: Author's generalization based on expert surveys 
DOI: 10.14807/ijmp.v11i8.1232

It is possible to break the process into separate blocks, namely:

a) transformation of the organizational forms traditionally existing for the administrative economic system according to market requirements;

b) introduction and acceleration of the elements of the land market;

c) implementation of modern market infrastructure;

d) development of the direct agrarian market of Ukraine;

e) deregulation of the domestic agrarian market;

f) legitimization of new organizational forms resulting from the formation of the market;

g) separate documents of situational and mainly regulatory content (which, incidentally, constitute the majority of adopted acts).

Undoubtedly, the adopted acts were dictated by the realities of life or carried out purposefully in order to achieve the effect of market transformations. Moreover, it is well known that the establishment of a market economy in Ukraine in the early 2000s, that is, the achievement of a (at least formally) basic objective.

The question is the reasons for the low efficiency of market reforms, as well as the persistence of a large number of problematic issues that have not yet been resolved, and their relevance is universally recognized, such as the land market, foreign economic integration, monetary policy, public policy in the agricultural sector in general, etc. In our opinion, such a contradictory situation was determined by the negative effect of the lack of logic of change in its legal support.

The dynamics of the main quantitative and qualitative indicators that characterized domestic agriculture in the period 1990-2020-ies testify to the above. Thus, the negative effect of the sharp curtailment of production volumes and efficiency of the industry in the first decade of the formation of a market economy is well known, as well as the continuation of stagnation in a number of positions and in the future. Undoubtedly, this was the result of the combined influence of many factors, including global trends that could not be regulated in Ukraine.

However, in world agricultural history, it is difficult to find similar facts when the process of curtailing production in the construction of the market (or - in general - with a radical modernization of the economy) took so long. Therefore, in our opinion, this duration, 
DOI: 10.14807/ijmp.v11i8.1232

among other things, was caused by the lack of systematic process of formation of the regulatory framework of changes.

On the other hand, only in 2003 the Laws of Ukraine "On Personal Farming" (LAW OF UKRAINE, 2003) and "On Farming" (LAW OF UKRAINE, 2003) were passed, that is, only 10 years after independence, the basic organizational form of agrarian business of a market type, which has long since become a leader, was legalized; as for the form of family farming, it only took place in 2016 (LAW OF UKRAINE, 2016).

At the level of the Eurasian Economic Union, the legal bases of agrarian policy are: Art. 94-95 of the EAEC Treaty, which declares its objectives, objectives and main directions; Protocol on State Support to Agriculture (ANNEX NO 29 TO THE EAEC TREATY); The concept of a coordinated (coordinated) agro-industrial policy (hereinafter the Concept) and a number of other normative-legal acts regulating tariff-customs, phytosanitary and other relations in the agricultural sphere.

The aim of the coordinated agro-industrial policy is to "effectively realize the resource potential of the Member States to optimize the production of competitive agricultural products and food, to meet the needs of the common agricultural market, and to increase the export of agricultural products and food" (Article 94 of Chapter XXV; TREATY ON THE EURASIAN ECONOMIC UNION, 2015).

The UAE sees this single policy and the common agricultural market as a new, closer stage of unification, where it is not enough to guarantee the free movement of goods, services, capital and labor, which is already characteristic of the European Economic Area.

In the EAEC Treaty, the solution of the problems of a coordinated agro-industrial policy involves the use of "mechanisms of interstate interaction" in such main areas as: forecasting in agroindustrial complex, state support of agriculture, regulation of the common agrarian market, common requirements in the field of production and sale of agricultural products food, scientific and innovative development of agroindustrial complex and integrated information support of agroindustrial complex.

Progress in particular areas of agreed agro-industrial policy is at different rates. So far, most progress has been made in forecasting and harmonizing the level of state support, compared to others, with specific figures for market distortions, though relative rather than absolute, which give countries considerable room for maneuver. However, if a country 
DOI: 10.14807/ijmp.v11i8.1232

becomes a member of the WTO, restrictions on the amount of state support already in absolute terms apply, which is also true for the UAE.

Countries, including Russia and Ukraine, have to amend their legislation to exclude measures that most distort the agrarian market. Yes, it is impossible to subsidize the sale of resources exclusively domestic producers (seeds, fertilizers or raw materials for processing, which was previously widely practiced).

However, there are contradictions. On the one hand, countries have declared a course on liberalization of agrarian markets, limited state support, but on the other, they believe that it forms a strong agroindustrial complex.

Very important in terms of the set of activities of the calendar plan is such an important direction as the joint development of exports of agricultural products and food. There is a provision where countries unilaterally decide to ban the export of a product or import without any agreement with the members of the Union.

Progress in the scientific and innovative development of the agroindustrial complex can be hindered by the comparative backwardness of the EAEU countries in comparison with the leading countries of the world - a repeated difference in the volume of refinement, the continuing closure of specialized research institutes.

It is necessary to strengthen the powers of the EEC in the pursuit of a single agricultural policy within the EAEU in order, first of all, to generate and distribute significant financial resources for the Union countries in support of agricultural producers. It would be appropriate, using the European experience, to adopt for the EAEU the basic principles of forming a common agricultural market in the form of market unity, the priority of its own agricultural products and financial solidarity (general budget).

In addition, it is important to pay particular attention to rural development in the UAEU and to set up a special joint fund to support small-scale farmers, the formation of agricultural cooperatives, the construction of rural infrastructure, the implementation of local rural development initiatives and measures to promote the full development of villages.

Thus, the process of legal formation of a market economy establishment in Ukraine appears to be sufficiently contradictory and inconsistent, as well as to the point that has only exacerbated the problem of reform effectiveness. 
DOI: 10.14807/ijmp.v11i8.1232

\section{CONCLUSIONS AND RECOMMENDATIONS}

The conducted study confirms the hypothesis that the legal block is an integral part of regulatory policy theory and practice. This a priori, at first glance, statement in each case describing the history of the formation of an industry market raises a number of further questions.

The author's position implies a clear understanding of the determinant role of the factor of legal support of the process of formation and functioning of a market economy as a logical and consistent process, the violation of which is accompanied by direct and indirect (e.g., loss of bonuses) losses of society.

The Ukrainian experience of formation, development of the agricultural market and formation of the legislative base, rather, convinces about the violation of such logic and consistency. In our opinion, from the economic point of view in Ukraine the basic legislative acts should be revised, and leading economists, scientists, lawyers and experts in the field of market paradigm should be engaged in their development and further improvement.

\section{REFERENCES}

ABALKIN, L. (1990) Ryinok ne terpit diletantstva. Ekonomika i zhizn, n. 21. (in Russian). ANDRIANOV, V. (1996) Gosudarstvennoe regulirovanie i mehanizmyi samoregulyatsii v ryinochnoy ekonomike. Voprosyi ekonomiki, n. 9. (in Russian).

ASHUROV, I. S. (2006) Agrarnaya politika v usloviyah perehodnogo perioda. Dushanbe: Irfon (in Russian).

BELYAEVA, Z. S. (1996) Agrarnaya reforma i izmenenie organizatsionno-pravovyih form selskohozyaystvennyih predpriyatii. Moskow (in Russian).

BOCHKOV, A. A. (2008) Modernizatsionnaya strategiya razvitiya APK regiona: institutsionalnyie izmeneniya, napravleniya, mehanizm. Krasnodar. Izd-vo Kubanskogo gos. agr. un-ta (in Russian).

BORISENKO, A. N. (1993) Investitsionnaya politika v agropromyishlennom komplekse v usloviyah ryinochnoy ekonomiki. Rostov na Donu: Litera-D (in Russian).

BYISTROV, G. E. (1999) Zemelnaya i agrarnaya reforma v zarubezhnyih stranah. Minsk (in Russian).

COASE, R. H. (1960) The Problem of Social Cost. Journal of Law and Economics, n. 3, p. $1-44$.

DATSII, O. I. (2005) Udoskonalennia mekhanizmiv derzhavnoho rehuliuvannia rozvytku novykh tekhnolohii i vysokotekhnolohichnykh ahropromyslovykh vyrobnytstv [Improvement of mechanisms of development state regulation of new technologies and high-tech agroindustrial industries]. Visnyk NADU, n 1, p. 180-187. (in Ukrainian). 
DOI: 10.14807/ijmp.v11i8.1232

DAVID, P. A. (2000) Path Dependence, its critics, and the guest for "historical economics". Stanford, CA: Economics Department. Working Paper, n. 00-011, p. 29-38.

DERYABINA, M. (2001) Institutsionalnyie aspektyi postsotsialisticheskogo perehodnogo perioda. Voprosyi ekonomiki, n. 2. (in Russian).

DOROFEEVA, H. H. (1996) Sovremennaya agrarnaya reforma: ekonomicheskiy i pravovoy aspekt: pravo i ryinok. Yuridicheskie zapiski: pravo i ryinok, v. 4, p. 77-86. (in Russian).

EPSHTEYN, D. B. (1992) Gosudarstvennoe regulirovanie selskohozyaystvennogo proizvodstva v usloviyah perehoda k ryinku (teoriya i metodologiya). Sankt-Peterburg (in Russian).

FOKIN, Yu. Korrektirovka ekonomicheskih reform ob'ektivnaya neobhodimost. Ekonomist, n. 3. (in Russian).

GAFUROV, X.; VOHIDOV, V. V. (2004) Model agrarnoy ekonomiki Tadzhikistana v XXI veke. Dushanbe (in Russian).

GUSCHIN, N. E. (2009) Sovremennaya gosudarstvennaya agrarnaya politika: pravovoe obespechenie. Vestnik Saratovskoy gosudarstvennoy, akademii prava, n. 1, p. 65-70. (in Russian).

HAIDUTSKYI, H. I. (1999) Hosprozrakhunkovyi mekhanizm mizhhaluzevykh zviazkiv v APK [Self-financing mechanism of inter-branch communication in agroindustrial complex]. Kyiv: Urozhai (in Ukrainian).

HAIVORONSKYI, V. M.; DUSHMAN, V. P.; KORNIIENKO, V. M. (2003) Ahrarne pravo Ukrainy [Agrarian law of Ukraine]. Kharkiv: Pravo (in Ukrainian).

KORETSKYI, M. H. (2002) Derzhavne rehuliuvannia ahrarnoi sfery u rynkovii ekonomitsi [State regulation of agrarian sphere in a market economy. Kyiv: Vyd-vo UADU (in Ukrainian).

KRAMON-TAUBADEL S. H.; ZORIA, S.; SHTRIVE L. (2001) Polityka ta rozvytok silskoho hospodarstva v Ukraini [Agriculture Policy and Development in Ukraine]. Kyiv : Alfa-Prynt (in Ukrainian).

LATYNIN, M. A. (2005) Teoretychni pidkhody shchodo vyznachennia mekhanizmu derzhavnoho rehuliuvannia rozvytku ahrarnoho sektoru ekonomiky Ukrainy [Theoretical approaches to defining the mechanism of state regulation of agrarian sector development of Ukraine`s economy]. Derzhavne upravlinnia: teoriia ta praktyka, n. 2. Available: <http://www.nbuv.gov.ua/eDjournals/DUTP/2005D2/txts/ golus/05/maseu.puf >. Access: 9 September 2019 (in Ukrainian).

MALIK, M. Y.; SHPYKULIAK, O. H.; LUZAN, O. Y. (2013) Instytuty y instytutsii u rozvytku intehratsiinykh protsesiv v ahrarnii sferi. The Economy of Agro-Industrial Complex, n. 4, p. 86-93. Available: http://eapk.org.ua/sites/default/files/eapk/13_04_12.pdf. Access: 11 September 2019

MALIK, M. Y.; SHPYKULIAK, O. H. (2019) Institutional analysis of entrepreneurship development in the agrarian sector of economy: methodical aspect. The Economy of AgroIndustrial Complex, n. 6, p. 73-77. DOI: https://doi.org/10.32317/2221-1055.201906073

MASLENNIKOVA, E. (1998) Gosudarstvennoe regulirovanie agropromyishlennogo proizvodstva v stranah ES. Ekonomist, n. 8. (in Russian).

MOROZ, O. V.; LOHOSHA, R. V.; PIDVALNA, O. H. (2019) Normative and legal regulation of the formation process of market mechanism in the agrarian economy. 
DOI: 10.14807/ijmp.v11i8.1232

Ekonomika APK, n. 5, p. 27-39. DOI: https://doi.org/10.32317/2221-1055.201905027 (in Ukranian)

NORTH, D. C.; ALT, J. (1990) Institutions, Institutional Change, and Economic

Performance. University of Illinois at Urbana-Champaign's Academy for Entrepreneurial Leadership Historical Research Reference in Entrepreneurship.

Available: <https://ssrn.com/abstract=1496212>. Access: 5 September 2019

NOVITSKIY, N. (2000) Innovatsionnyiy put razvitiya ekonomiki. Ekonomist, n. 6. (in Russian).

PAPTSOV, A. G. (1991) Gosudarstvennoe subsidirovanie agrarnogo sektora v razvityih stranah mira. Moskow: VNIITEIAPK (in Russian).

PAVLOVA, E. I. (1998) Gosudarstvennoe regulirovanie selskogo hozyaystva vo Frantsii. Organizatsionno-pravovyie aspektyi. Moskow: Nauka (in Russian).

POPOV, H. A. (1999) Ekonomika selskohozyaystvennogo proizvodstva s osnovami ryinochnoy ekonomiki i selskogo predprinimatelstva. Moskow: EKMOS (in Russian).

POSTANOVA KABINETU MINISTRIV UKRAINY «Pro Derzhavnyi tekhnolohichnyi tsentr okhorony rodiuchosti gruntiv» [Resolution of the Cabinet of Ministers of Ukraine "On the State Technological Center for Soil Fertility Protection"] vid 04.08.2000 r. n. 1218. Avaible: <https://zakon.rada.gov.ua/laws/show/1218-2000-\%D0\%BF>. Access: 10 September 2019 (in Ukrainian).

POSTANOVA KABINETU MINISTRIV UKRAINY «Pro zatverdzhennia normatyviv optymalnoho spivvidnoshennia kultur u sivozminakh $\mathrm{v}$ riznykh pryrodnosilskohospodarskykh rehionakh» vid 01.02.2010 r. №164 [Resolution of the Cabinet of Ministers of Ukraine "On approval of the norms of the optimum ratio of crops in crop rotation in different natural and agricultural regions”]. Avaible:

<https://zakon.rada.gov.ua/laws/show/164-2010-\%D0\%BF>. Access: 10 September 2019 (in Ukrainian).

POSTANOVA TSK KPRS I RADY MINISTRIV SSSR «Pro zakhody shchodo posylennia borotby $z$ netrudovymy dokhodamy» vid 24 chervnia 1986 r. № 235 [CPSU Central Committee and the Council of Ministers of the USSR, on measures to strengthen the fight against non-labor income]. Avaible: <https://zakon.rada.gov.ua/laws/show/235-86\%D0\%BF>. Access: 9 September 2019 (in Ukrainian).

POSTANOVA TSVK I RNK SRSR «Pro okhoronu maina derzhavnykh pidpryiemstv, kolhospiv i kooperatsii ta zmitsnennia suspilnoi (sotsialistychnoi) vlasnosti» [Resolution of the CEC and RNA of the USSR "On the protection of property of state-owned enterprises, collective farms and cooperatives and the strengthening of public (socialist) property"]. Hazeta «Bilshovyk Poltavshchyny». 07.08.1932 r. Avaible:

<http://www.territoryterror.org.ua/uk/archive/photoarchive/photo/?pictureid=577>. Access: 5 September 2019 (in Ukrainian).

PRYLUTSKYI, A. M. (2017) Rehuliatyvna rol derzhavy u posylenni rozvytku ahrarnoho rynku [The regulatory role of the state in strengthening the development of the agricultural market]. Ahrosvit, n. 9, p. 24-29 (in Ukrainian).

PRYSIAZhNIUK, M. V.; ZUBETS, M. V.; SABLUK, P. T. (2011) Ahrarnyi sektor ekonomiky Ukrainy (stan i perspektyvy rozvytku) [Agrarian Sector of Ukrainian Economy (State and Prospects for Development]. Kyiv: NNTs IAE (in Ukrainian). 
SABLUK, P. T.; MESEL-VESELIAK, V. I. (2002) Stratehichni napriamy rozvytku ahropromyslovoho kompleksu Ukrainy [Strategic directions of development of agroindustrial complex of Ukraine]. Kyiv : IAE. (in Ukrainian).

SABLUK, P. T. (2011) Orhanizatsiino-ekonomichna modernizatsiia ahrarnoi sfery: nauk [Organizational and economic modernization of the agrarian sphere: Sciences. ext]. Kyiv : NNTs IAE. (in Ukrainian).

SAGAYDAK, A. (2002) Opyit gosudarstvennogo regulirovaniya v selskom hozyaystve SShA. APK: ekonomika, upravlenie, n. 8, p. 26-33. (in Russiann).

SEROVA, E. (1996) Osobennosti gosudarstvennoy podderzhki agrarnogo sektora v Rossii. Voprosyi ekonomiki, n. 7, p. 92-96. (in Russiann).

SHKURENKO, A. V. (2015) Formation of the Common Agrarian Market in the EU: Lessons for the Eurasian Economic Union. Eurasian Economic Integration, v. 4, n. 29, p. 73-94.

SHPIKULYAK, A. H. (2010) Institutions in the development and regulation of the agricultural market: monograph. Kyiv: NSC IAE (in Ukranian)

TAMBOVTSEV, V. (1998) Institutsionalnaya dinamika v perehodnoy ekonomike. Voprosyi ekonomiki, n. 5. (in Russian).

TREATY ON THE EURASIAN ECONOMIC UNION (Astana, May 29, 2014) (as amended on May 8, 2015; revised on October 1, 2015). Avaible:

$<$ http://docs.cntd.ru/document/420205962. . . Access: 8 September 2019 (in Russian).

VDOVENKO N. M.; NAKONECHNA K. V.; SAMSONOVA, V. V. (2017) Mechanisms and tools of supply regulation in agricultural sector of economy. Scientific Bulletin of Polissia, v. 3, n. 11, part 1, p. 165-169. DOI: 10.25140/2410-9576-2017-1-3(11)-165-169.

VDOVENKO, N. M.; BOHACH, L. V. (2017) Scientific substantiation of the reduction of import dependence in the markets of agricultural products. Scientific Bulletin of Polissia, $\mathrm{n}$. 2 (10), p. 13-17. Available: http://nvp.stu.cn.ua/en/component/k2/item/696-vdovenko-n-mbohach-l-v-scientific-substantiation-of-the-reduction-of-import-dependence-in-the-marketsof-agricultural-products.html. Access: 12 September 2019.

VDOVENKO, N. M.; NAKONECHNA, K. V.; PAVLENKO, M. M. (2017) Methodical component of the performance of state support producers mechanism. Scientific Bulletin of Polissia, v. 4, n. 12, part 1, p. 22-27. DOI: 10.25140/2410-9576-2017-1-4(12)-22-27.

YANGIBOEV, B. (2004) Upravlenie agrarnoy sferyi v usloviyah perehoda $\mathrm{k}$ ryinochnyim otnosheniyam: printsipyi i napravleniya. Ekonomika i statistika, n. 2. (in Russian).

ZAKON «Pro zahalni zasady pidpryiemnytstva v SRSR» vid 26.05.1987 r. № 8998 [Law "On General Principles of Entrepreneurship in the USSR"] (1987) Avaible:

$<$ http://search.ligazakon.ua/__doc2.nsf/link1/Z728400.html>. Access: 5 September 2019 (in Ukrainian).

ZAKON SRSR «Pro derzhavne pidpryiemstvo (obiednannia)» vid 30.06.1987 r. № 7284XI [Law of the USSR “On State Enterprise (Association)"] (1987) Avaible:

$<$ http://search.ligazakon.ua/__doc2.nsf/link1/Z728400.html>. Access: 5 September 2019 (in Ukrainian).

ZAKON SRSR «Pro indyvidualnu trudovu diialnist» vid 15.04.1987 r. № 127 [Law USSR "On Individual Labor Activity"] (1987) Avaible: <https://zakon.rada.gov.ua/laws/show/12787-\%D0\%BF>. Access: 5 September 2019 . (in Ukrainian). 
DOI: 10.14807/ijmp.v11i8.1232

ZAKON SRSR «Pro kooperatsiiu» vid 26.05.1988 r. N 8998-11 [Law of the USSR "On Cooperation"] (1988) Avaible: <https://zakon.rada.gov.ua/laws/show/v8998400-88>. Access: 4 September 2019 (in Ukrainian).

ZAKON UKRAINY «Pro okhoronu zemel» vid 19.06.2003 r. (№ 962-IV) [Law of Ukraine "On Land Protection"] (2003) Avaible: <https://zakon.rada.gov.ua/laws/show/962-15>. Access: 6 September 2019 (in Ukrainian).

ZAKON URSR «Pro priorytetnist sotsialnoho rozvytku sela ta ahropromyslovoho kompleksu v narodnomu hospodarstvi» vid 17.10. 1990 r. № 400-XII [Law of the USSR "On the priority of social development of the village and agro-industrial complex in the national economy"] (1990) Avaible: <https://zakon.rada.gov.ua/laws/show/40012/ed19901017/sp:wide:max100>. Access: 6 September 2019 (in Ukrainian).

ZAKONY UKRAINY «Pro fermerske hospodarstvo» vid 19.06.2003 r. № 973-IV [Laws of Ukraine "On Farming"] (2003) Avaible: <https://zakon.rada.gov.ua/laws/show/973-15>. Access: 8 September 2019 (in Ukrainian).

ZAKONY UKRAINY «Pro osobyste selianske hospodarstvo» vid 15.05.2003 r. №742-IV [Laws of Ukraine "On Personal Farming"] (2003) Avaible:

<https://zakon.rada.gov.ua/laws/show/742-15>. Access: 8 September 2019 (in Ukrainian).

ZAKONY UKRAINY «Pro vnesennia zmin do Zakonu Ukrainy «Pro fermerske hospodarstvo» shchodo stymuliuvannia stvorennia ta diialnosti simeinykh fermerskykh hospodarstv» [Laws of Ukraine "On Amendments to the Law of Ukraine" On Farming "on Promoting the Creation and Operation of Family Farms"] vid 31.03.2016 r. № 1067-VIII (2016) Avaible: <https://zakon.rada.gov.ua/laws/show/1067-19>. Access: 8 September 2019 (in Ukrainian).

ZELDNER, A. (2000) Prioritetyi i mehanizmyi vyihoda agrarnoy sferyi izgkrizisa v XXI vek. Moskow: Institut Ekonomiki RAN (in Russian).

THE EUROPEAN UNION'S COMMON AGRICULTURAL POLICY: PRESSURES FOR CHANGE (1999) United State Department of Agriculture. International agriculture and trade reports. WRS-99-2 / October 1999. 